\title{
CLASSICAL ARCHITECTURE IN THE SCOPE OF KANTIAN AESTHETICS: BETWEEN LYOTARD AND RANCIÈRE
}

\section{Helen Tatla}

University of West Attica

lenatatla@uniwa.gr

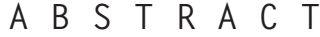

Classical architecture's inherent potentiality to constitute the principal architectural expression of western culture since Greek antiquity is due to its dual character: although it comes out from the primordial unity of things expressed by myth and religion in archaic times, it acquires its form of completion in the fifth $\mathrm{c}$. $\mathrm{BC}$, as a symbol of democracy and a harmonic articulation of the world on the ground of philosophical thinking.

By placing the avant-guard art in the sphere of the Kantian sublime, Jean-Francois Lyotard focuses on the impossibility of an absolute relation between reason and perception or between thinking and image, in modernity. He considers that in cases where this happens, it gives birth to political monsters. He connects postmodern expressions of classicism in architecture with Freud's "Interpretation of Dreams" and the Kantian beautiful.

Jacques Ranciere's approach to a Kantian in basis aesthetic consideration of modernity is opposite to that proposed by Lyotard. Instead of the sublime, Ranciere relates the beautiful with the rupture between thinking and perception . In this respect, fragments of the past can stimulate a creative procedure in the present.

This investigation aims to contribute to the dialogue for a renovated approach to the role of classicism in architecture today.

KEY WORDS

CLASSICAL ARCHITECTURE

KANT

LYOTARD

MODERNITY

POLITICS

POSTMODERNITY

RANCIÈRE 


\section{INTRODUCTION}

In an attempt to give an ontological account of Classical architecture, we go back to ancient Greece, where we can discern two main historical periods. A preclassical or archaic one (seventh-sixth centuries BC), in which we could argue that architecture is born as an expression of religious and mythical thinking. As the oldest surviving temples suggest, architecture comes out in a complete form from the very beginning. The emphasis on a harmonic articulation of the parts of an already given form characterizes mainly the fifth century BC and belongs to the Classical period. Now, architectural form that originated in myth and religion becomes a symbol of the democratic principles of the polis (city-state) through a process which was consequently extended to public and private buildings as well. ${ }^{1}$ There is no contradiction in this. As Aristotle puts it in Politics, God and reason alone govern the city-state. ${ }^{2}$ Human and devine law coexist. As far as architecture is concerned, the matter of mathematical harmony is accompaned by an emphasis on the symbolic function of stoa or peristilion (a series of columns), which is gradually added around public and private open spaces in order to support the idea of democracy primarily expressed by the agora as an open space at the heart of the city.

Consequently, we could argue following Friedrich Nietszche, that premordial unity between man, nature and the divine on the one hand, along with democratic regulative principles which underly the mathematical articulation of form on the other, endow Classical Greek architecture with the potentiality to constitute the principal architectural expression of western culture since Greek antiquity. It is this ability to express myth and reason or religion and democracy simultaneously that gave it a new role in the Enlightenment as well as Modernity, initiated by the Renaissance in the fifteenth century.

The impact of classical architecture on modern, postmodern and contemporary architectural experimentation will be examined next, not in terms of sociocultural and historical continuity, which would imply a sort of zeitgeist implicit in its power to survive, as the phenomenological speculative thinking of Martin Heidegger or Hans-Georg Gadamer would suggest, for instance. It is not a condition of unity between reason and sensation provided by imitation on the basis of the Platonic opposition between the idea and its sensible image what engages us here, but quite the opposite. Classical architecture is put within the scope of Kantian aesthetics. Thus it can motivate the beautiful or the sublime sentiment within human mind as an open, sometimes impossible relation between reason and sensation. 
We will next turn to Lyotard's approach to the postmodern in art and architecture through Kant's aesthetic of the sublime feeling on the one hand as well as Rancière's approach to an aesthetic consideration of modernity on the basis of the Kantian beautiful on the other, with reference to Classical architecture.

\section{LYOTARD: POSTMODERN AND THE SUBLIME}

In his Complexity and Contradiction in Architecture, published by MoMA in 1966, Robert Venturi launched a war against Modernist Eucledian clarity and rational functionality. ${ }^{3}$ By using more than 200 paradigms from architectural history, mainly refering to eclectial, mannerist and baroque classicism, he insists that complexity, ambiguity and contradiction are principal characteristics of architecture since the Vitruvian firmitas, utilitas, venustas. Venturi's book contributed to a major debate in architecture, which dealt with a critical reconsideration of the classical past and culminated in the next two decades of postmodernism. The first Venice Biennale of architecture, organised by Paolo Portoghesi in 1980 under the title The Presence of the Past, could be considered as a celebration of the postmodern conqueries of the 1970s. Twenty well known achitects, such as Leon Krier, Massimo Scolari, Rem Koolhaas and Elias Zegelis, Frank O. Gehry, Arata Isozaki, Hans Hollein and others, undertook the design of consecutive exhibition spaces with elevations between the columns in the interior of the old shipyard (Corderie). A double sequence of elevations frame La Strada Novissima on both sides, creating a bricolage of postmodern eclecticism. ${ }^{4}$

Next, we will attempt to relate this kind of reference to classical architecture in the 1970s and the 1980s with the meaning Lyotard gives to the term postmodern, by introducing it to philosophy. Lyotard uses the term postmodern for the first time in his book The Postmodern Condition: A Report on Knowledge first published in 1979, in order to describe the condition of knowledge in the mostly developed societies in the context of what he calls "the crisis of grand narratives". ${ }^{5}$ It becomes clear in his seminal essay "Answering the Question: What is Postmodernism?"(1982) included as an appendix in this book, that when he defines postmodern as "incrudelity to the metanarratives", what he rebels against is an all-embracing, totalising, and unifing vision about society. In this context, he insists that postmodernity is endowed with the task of constantly imposing a severe critique of the Enlightenment idea of a unitary end of history and the subject, which is close to the spirit of Kant's Critique of Judgement and was originally initiated by Ludwig Wittgenstein and Theodor Adorno. In this respect, he accuses Habermas that his attempt to unify cognition, ethics 
and politics through language aims to a totalising experience that originates in Hegelian dialectics. ${ }^{6} \mathrm{He}$ writes: 'The nineteenth and twentieth centuries have given us as much terror as we can take. We have paid a high enough price for the nostalgia of the whole and the one, for the reconciliation of the concept and the sensible [...].' ${ }^{7}$ The consensus proposed by Habermas, 'does harm to the heterogeneity of the language games. [...] Postmodern knowledge is not simply a tool to the authorities; it refines our sensitivity to difference and reinforces our ability to tolerate the incommesurable. Its principle is not the expert's homology but the inventor's paralogy. ${ }^{8}$

In a text entitled "Defining the Postmodern", presented at a conference on postmodern art and architecture held by the Institute of Contemporary Arts in London in 1985, Lyotard refers to the Italian architect and theorist Vittorio Gregotti, who insists that the urban project of rebuilding the whole space occupied by humanity on rational, universally valid principles undertaken by modern architecture has failed. As a result, Lyotard observes, "postmodern architecture is condemned to generate a multiplicity of small transformations in the space it inherits. [...] a sort of bricolage: [...] quotations of elements from previous styles or periods (classical or modern) ... ${ }^{9}$

Lyotard, although he shares with the proponents of architectural postmodernism a distaste for the urban project of the realization of the grand narrative of modernism on a universal scale, he expresses two reservations the discussion of which will elucidate further the essential differences between the meaning he gives to the term postmodern and the meaning of the term in the classical eclecticism of the 1970s and the1980s.

First, he explains that the idea of putting events and things in chronological order is totally modern so far as it belongs to Christianity, Cartesianism, and Jacobinism. In the case of classical eclecticism in architecture, Lyotard considers that the post- of the postmodern intends to signify a chronological category, a period of time which comes after the modern. He is totally opposed to this distinction between modernity and postmodernity as a simple succession of periods. As he discusses in his text "Rewriting modernity", the first version of which was presented in 1986, modernity is always pregnant with postmodernity as far as 'modern temporality comprises in itself an impulsion to exceed itself into a state other than itself.' 10

Secondly, he maintains that breaking with tradition and reseting the clock at zero by modernity, is a manner of repressing the past and repeating it rather than overcoming it. However, the quotation of elements of past architectures 
by postmodern architecture is in fact the same procedure as the use of remains coming from past life in the dream-work as described by Sigmund Freud in the Interpretation of Dreams. As such, it cannot be a real solution to the problem of breaking with the past.

In "Rewriting Modernity", Lyotard finds a parallel between Freud's approach to dreams and the Kantian beautiful. ${ }^{11}$ In this respect, he opposes the dream work in favor of the anamnesis of psychoanalytic therapy. He insists that in the context of psychoanalysis rewriting provides no knowledge of the past. According to Freud, psychoanalysis is not subject to knowledge but merely a "technique". ${ }^{12}$ In addition, Lyotard finds a counterpart between Kant's notion of the sublime and what Jacques Lacan called the Thing and Freud the unconscious affect. Thus, rewriting concerns the anamnesis of the Thing and as such it comes under a problematic of the sublime. ${ }^{13}$

As he states in The Postmodern Condition:

'The sublime sentiment, [...] carries with it both pleasure and pain. Better still, in it pleasure derives from pain. This contradiction, [...] which some would call neurosis or masochism, develops as a conflict between the faculties of a subject, the faculty to conceive of something and the faculty to "present" something. ${ }^{\text {" }} 4$ "The postmodern would be that which, in the modern, puts forward the unpresentable in presentation itself. ${ }^{15}$

Lyotard considers that it was the avant-guard painters who carried out the highly responsible project of the investigation of the presuppositions implied in modernity. He compares their work to the psychoanalytic therapy. The characteristic symptom of neurosis or psychosis is repetition and it organises the whole existence of the subject like a drama, he writes. ${ }^{16}$ In psychoanalytic therapy the patient elaborates his trouble by freely associating past situations, so discovering hidden meanings of his life. Cezanne, Picasso, Delaunay, Kandinsky, Klee, Mondrian, Malevitch and finally Marcel Duchamp have worked through what Freud called Durcharbeitung, thus overcoming the modern neurosis or schizophrenia, Lyotard insists. Anamnesis replaces repetition. ${ }^{17}$ The postmodern in architecture thus understood seems to us to be closer to works characterised as deconstructive in the MoMA exhibition of 1988, organised by Philip Johnson and Mark Wigley. The works by Frank O. Gehry, Rem Koolhaas, Peter Eisenman, Daniel Libeskind, Coop Himmelblau, Zaha Hadid and Bernard Tschumi were selected for the exhibition. As it appears in the text of the press release from March 1988, the intention of the above architects was 
'to address, in Johnson's words, the "pleasures of unease". [...] Their projects continue the experimentation with structure initiated by the Russian Constructivists, but the goal of perfection of the 1920s is subverted. The traditional virtues of harmony, unity, and clarity are displaced by disharmony, fracturing, and mystery. ${ }^{2} 18$

What we suggest here is that they seem to be connected to classicism through a psychoanalytic process of "elaborating an initial oblivion".

\section{RANCIÈRE:}

\section{RUPTURE AS THE GROUND FOR A FREE PLAY BETWEEN REASON AND PERCEPTION}

Rancière shares with Lyotard an aesthetic consideration of modernity which is Kantian in essence. They both deal with the rupture between thinking and perception in Kant's Third Critique. Nevertheless, while Lyotard focuses on the sublime, Ranciere insists in renovating the meaning of the beautiful. Rancière uses the term dissensus in order to describe the relation between thinking and perception in the Kantian beautiful as a rupture. This brings to mind the early apologist of the Cubist movement Maurice Raynal, who first associated the Kantian beautiful to Cubist art that favours distortion, fragmentation and dislocation instead of representation. ${ }^{19}$

Rancière rejects any equation of Kant's definition of the beautiful as 'what is presented as an object of universal delight apart from any concept ${ }^{20}$ with the traditional definition of beauty as harmony. He also fiercely opposes the connection of this rupture to Kant's definition of the sublime. He identifies a radical break with representation not in Kant's conception of the sublime but in the phrase "apart from any concept".

With reference to Schiller's letters "On the Aesthetic Education of Man" that originated in Kant's Analytic of the Beautiful, Rancière attributes a political role to aesthetics grounded not on a causal or dialectic or other relation, but on a free play between thinking and perception as the basis for a democratic articulation of a society. In this respect, fragments of the past can stimulate a creative procedure in the present. In opposition to Lyotard within this conceptual scheme, Rancière has no need for psychoanalysis in order to handle rupture, while he poses the relation between thinking and perception as a relation of equals. Rancière uses Schiller's conception of an aesthetic state as the manifesto of his conception of modernity as the "aesthetic regime of the arts" as far as it 
indicates a special identity of opposites between thinking and art's perception or between life and the autonomy of art. As Rancière explains, the "aesthetic state" is 'a pure instance of suspension, a moment when form is experienced for itself'. Art's autonomy is defined by him in this way. ${ }^{21}$

Thus, he maintains that the rejection of the concept of mimesis by modernity implies art's liberation from specific rules, hierarchy, subject matter and genres. More than that, he insists that mimesis separates the way of doing and making arts from the order of social doings. The aesthetic regime he proposes identifies the forms of art with those which express the shape of life, while simutaneously it defends the absolute singularity of art. Thus, it sets the foundations of the autonomy of art on the Schillerean conception of an aesthetic state. ${ }^{22}$ Rancière shares Adorno's aversion to any form of assimilation of art to life and his persistence on the radical separation of the work from aestheticised commodities. He, however, opposes Adorno's conception that the work has to become even more mechanical and "inhuman" in relation to mass consumption in order to denounce the capitalist division of work and the embellishments of commodities. Rancière claims that this is against art's autonomy. ${ }^{23}$

Rancière further argues that the dissensual operation implied in Kant's definition of the beautiful involves a superimposition that transforms the given form or body to a new one. In order to support his point of view, he cites the work of Johann Joachim Winckelmann. In his History of Ancient Art, published twenty-six years before Kant's Critique of Judgement, Winckelmann selected a crippled and beheaded statue, known as the Belvedere Torso, as the masterpiece of Greek art. The paradox is intensified by the fact that Winckelmann considers the statue as a representation of Hercules..$^{24}$ Rancière finds an analogy between the Belvedere Torso and the Deleuzian "body without organs". ${ }^{25} \mathrm{He}$ considers Deleuze's approach to Bacon's athletic figures in his Logic of Sensation as an heir to the Schillerian conception of liberty that has disappeared as the political liberty of people. On this ground, he criticises Deleuze's insistence on the sublime dramaturgy. In a process of subtraction and addition, Winckelmann reinvents with his words the shape and meaning of Greek statues. In this way, the Belvedere Torso or Bacon's mutilated figures could evoke a new sense of community. ${ }^{26}$ This would suggest a similar operation for classical works of architecture, of course. Thus, the Parthenon, for instance, like the Belvedere Torso or a Bacon's body, through mutilation and dismemberment can motivate a disenssual operation as a play of subtraction and addition free of any particular rules or symbolism and thus become an expression of social emancipation in modernity. 
Rancière refers to the example of the museum in order to elucidate the meaning of dissensus further in relation to everyday experience. If we use the Archeological museum of Athens as a paradigm, the works exhibited inside the museum have been removed from their original destination and the specific community in which they belonged. In the new environment there are no boundaries whatsoever separating the realm of art and the realm of everyday life. All representations are offered to the same indifferent gaze. Aesthetic separation does not imply a private paradise for amateurs or aesthetes, claims Rancière. This is why Schiller after reading Kant's Third Critique could not conceptualise a community united by the vision of eternal beauty. The aesthetic effect in fact derives from a relationship between two "separations". Before entering the realm of aesthetic experience in the museum, the works had been produced for a particular destination: festivities and religious ceremonies, building decorum, etc. The entering in the aesthetic sensorium of the museum is marked with the loss of destination. Along with the loss of the harmony between poiesis and aisthesis, the relation between each work and its particular place in the social order, identified with relations of dominance and inequality, has also been lost in the museum's environment. The meaning of the word loss here is different from the loss of the aura as its unique relation in space and time, according to Benjamin. ${ }^{27}$ Social emancipation is not related to the mechanical reproduction of an archetype. Social emancipation for Rancière becomes an aesthetic matter, a matter of dismemberment of a body animated by a particular belief. ${ }^{28}$

When the loss of destination implicit in aesthetic experience, as explained by Rancière, disrupts the way in which bodies fit their functions in a social order, then a political effect is produced. It consists in 'a multiplicity of folds and gaps in the fabric of common experience that change the cartography of the perceptible, the thinkable and the feasible'. ${ }^{29}$ The political effect, Rancière claims, occurs under the condition of an original disjunction, which separates cause and effect. The aesthetic effect presupposes dis-identification. Within the aesthetic community, political subjectivisation is based on a dis-identification process. We can argue that within modernity, classical architecture looks like the exhibits of the museum: a loss of the harmony between poiesis and aisthesis, between the intention of the creator and the aesthetic experience of the inhabitant or the visitor and a loss of the hierarchical order between the work and its environment.

In this respect, Rancière suggests that the meaning of modernity is not aesthetic innovation as such, but the invention of aesthetic forms and material structures referring to a life to come. He maintains that aesthetic avant-guard has led to 
political avant-guard, or at least tried to: the transformation of politics into a total life programme through an aesthetic appreciation of reality based on sensation. Rancière uses the example of Russian Constructivism in order to clarify what he means when he talks about a fusion of art and life through his concept of dissensus. In a lecture given in the Oslo Astrup Fearnley Museet in 2016, entitled "Art and politics: Dissensus and its metamorphoses" 30 , he refers to a replica of the Tatlin's model for the Monument of the Third International (1919), made by the Chinese artist Ai Weiwei in 2007 for the city of Liverpool. Standing on a floating platform in the shape of a spectacular chandelier and named "Work in progress/fountain of light", at a first glance, the replica might suggest a postmodern parody. It was a copy of the model of a 303-meter high architectural construction consisting of two interlaced, progressively diminishing spirals. Within the spirals four large transparent rotating volumes were suspended dedicated to the purposes of legislation, administration, information and cinematic projection respectively. The whole construction was conceived to be made of iron and glass, because these two materials share - according to a contemporary description - 'an imposing simplicity and at the same time $[\ldots]$ for both [...] fire is the creator of life'. ${ }^{31}$ As the architectural critic and historian Kenneth Frampton observes 'one can hardly regard the tower as a purely utilitarian object.' It remains rather 'a monumental metaphor of a new social order'. ${ }^{32}$

Rancière explains that Tatlin's monument constitutes a dissensual proposition as far as keeping a distance from the past it proposes new forms of estrangement which are supposed to reform our perception. As a material transformation of the life in the landscape of the community, art intertwines with life, artistic practice with political practice. He observes that architecture is par excellence, the art that achieves this unity of art and life. It constructs the sense of space. Tatlin's monument, along with projects by Lissitzky, Ladovsky, Melnikov, Rodchenko and other artists and architects of the Russian avant-guard, through impossible spaces and paradoxical temporality, propose new forms of visibility, which aim to transform the visible landscape, to shape new forms of life and to change the old world. Intentionally "unrealisable" as Frampton comments, Lissitzky's 1920 design for a Lenin tribune was projected as a Proun. He coined the term from Pro-Unovis, 'project for the affirmation of new forms of art', in order to indicate 'an unprecedented creative realm, situated somewhere between painting and architecture'. ${ }^{33}$

Understood in this way, aesthetics does not suggest a philosophical discourse aiming to dominate art or architecture. Rather it suggests an attempt to activate thinking by pointing to the work's paradoxes and contradictions. Thus, 
dissensual perception or a dissensual intervention in the public space implies dislocation, dismemberment and dis-identification of given, established truths, while it still remains within the spectrum of the Kantian indifferent gaze. As such, it contributes to a perpetual free play between thinking and perception conceived as equals. In this way, art opens up its limits to other art species and perceptual means, while it participates in a political operation in terms of autonomy and equality.

\section{CONCLUSION}

A fundamental feature of the ontology of modernity is the fact that $\mu$ í $\mu \eta \sigma \varsigma$ imitation - retreated in favour of a rupture between thinking and perception, principally expressed by Kant in his Third Critique. Mí $\mu$ бıৎ in Classical times, as both Plato and Aristotle agree, implied the existence of the sensibles as corporeal expressions of a metaphysical - that is to say unchangeable in space and time - archetype. Mím $\sigma \iota \varsigma$ originally indicates unity between thinking and perception on a social/political ground. The opening of the gap in modernity is interwoven with concepts of political freedom and human emancipation.

Lyotard severely criticises the grand narrative of modernity concerning the belief that human emancipation at a universal scale will be achieved through scientific progress and technology and counterposes a philosophical account of postmodernism as the quintessence of modernism. In order to define postmodernism, Lyotard focuses on the Kantian sublime sentiment. The sublime sentiment excludes any direct relation between reason and imagination or between thinking and perception. Thus, for Lyotard the only way to approach the past is through psychoanalysis. Psychoanalytic anamnesis seems to him to be the only secure method to avoid repetition or any attempt of resurrection of a whole, in political terms. He relates the classical references of postmodern architecture of the 1970s and the 1980s with the function of the dream world as it is approached by Freud. He relates this to the Kantian beautiful. The appeal to the dream world cannot guarantee, Lyotard claims, that the neurosis or psychosis caused by the repression of the past by modernity will not lead to its repetition. He insists that the avant-guard painters only managed to overcome repetition through a working process which recalls psychoanalytic therapy.

In an attempt to keep the relation between thinking and sensation active, Rancière on the other hand interprets the Kantian phrase "apart from a concept" from the Second Moment of the "Analytic of the Beautiful" in terms of an aesthetic distance established between the two. This allows for the operation of a free play between them. 
Rancière refers to classical art and uses the paradigm of the museum in order to describe the dissensual operation of the Kantian beautiful. In this respect, classical works acquire aesthetic/political value in modernity only through disidentification and the loss of their hierarchical status within their environment. An aesthetic effect can be produced only if the way in which classical works fit their functions in their particular social order is disrupted. Thus, deprived of the ability to be carriers of any particular truth, they become subject to a free play between thinking and perception on the ground of a dissensual operation. Rancière explains that Tatlin's model for the monument of the Third International constitutes a dissensual proposition as far as, through an indifferent gaze to the past, it conceptualises new, "intentionally unrealisable" forms, which aim to unify art and life. 
Helen Tatla, "Idea and Freedom: The Search for Form in Classical Architecture and the Modern Movement“ (Ph.D. Thesis, University of Edinburgh), publ. in: https://www.era.lib.ed.ac.uk/ handle/1842/6988.

Aristotle, The Politics, I,2, trans. H. Rackham (London: Loeb Classical Library, William Heinemann Ltd., 1932); see discussion in: III, XI, 4-5.

Robert Venturi, Complexity and Contradiction in Architecture (New York: Museum of Modern Art Papers on Architecture, c/1966).

See discussion in: Josep Maria Montaner, History of Contemporary Architecture Movements, Ideas

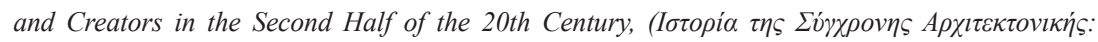

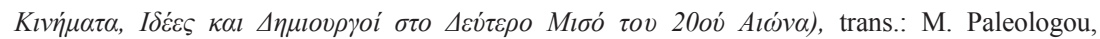
A.Giakoumakatos (Nefeli: Athens, 2014), 421-422.

Jean-Francois Lyotard, The Postmodern Condition: A Report on Knowledge, intr. Frederic Jameson, trans. Geoff Bennington \& Brian Massumi (Minnesota: University of Minnessota, 1984), xxiii.

Ibid., 72-73.

Ibid., 81-82.

Ibid., xxv.

Jean-Francois Lyotard, "Defining the Postmodern," in ICA Documents 4, Postmodern, ed. Lisa Appignanesi (London: Institute of Contemporary Arts, 1986), 6-7.

Jean-Francois Lyotard, The Inhuman, trans. Geoffrey Bennington \& Rachel Bowlby (Stanford: Stanford University Press, 1991), 25.

Op. cit., Lisa Appignanesi ed., 6-7.

Ibid., 31.

Ibid., 33.

Op. cit., Lyotard, The Postmodern Condition: A Report on Knowledge, 77.

Ibid., 81.

Op. cit., Lyotard, The Inhuman, 26.

Ibid.

Press release: http://www.moma.org/docs/press archives/6526/releases/MOMA 1988002929. pdf/2010. Philip Johnson and Mark Wigley prefered not to relate the exhibition to the philosophy of Jacques Derrida in particular. They rather chose to present it as an experimentation in architecture on the ground of Russian Constructivism.

Maurice Raynal,“Some Intentions on Cubism,“ In Cubism, ed. Edward Fry (London: Thames \& Hudson, 1978), 153-155.

Jacques Rancière, The Emancipated Spectator, 64ff. For Kant's Second Moment of the Analytic of the Beautiful, see for instance: Immanuel Kant, The Critique of Judgement, trans. James Creed Meredith (Oxford: At The Clarendon Press, 1969), 50-60.

Jacques Rancière, The Distribution of the Sensible: Politics \& Aesthetics, trans. Gabriel Rockhill (London: Continuum, 2004), 10, 22ff.

Jacques Rancière, Aesthetics and its Discontents, trans. Steven Corcoran (Cambridge: Polity Press, 2009), 39-41.

Johann Joachim Winckelmann, History of Ancient Art, trans. Giles Henry Lodge (Boston: James Munroe \& Co, 1849), Vol. II, 234, in particular.

Gilles Deleuze, Francis Bacon: the logic of sensation, trans. Daniel W. Smith (London: Continuum, 2004), 44ff., in particular. 
Rancière, The Emancipated Spectator, 64-67.

Walter Benjamin, "The Work of Art in the Age of Mechanical Reproduction,” In Illuminations, ed. Hannah Arendt, trans. Harry Zohn (New York: Schocken Books, 1969), 217-251.

Rancière, The Emancipated Spectator, 69-71.

Rancière, The Emancipated Spectator, 72. See further discussion in: 72-73.

https://www.youtube.com/watch?v=b3CKIZgwf3k.

Kenneth Frampton, Modern Architecture: A Critical History (London: Thames \& Hudson, 1980), 171.

Ibid., 170-171.

Ibid., 170 . 
Adorno, Gretel and Rolf Tiedmann eds, Theodor Adorno- Aesthetic Theory, intr. \& trans. Robert Hullot-Kentor. London: The Athlone Press Ltd, 1977.

Appignanesi, Lisa ed., ICA Documents 4, Postmodern. London: Institute of Contemporary Arts, 1986.

Aristotle, The Politics, I,2, trans. H. Rackham. London: Loeb Classical Library, William Heinemann Ltd., 1932.

Benjamin, Walter. "The Work of Art in the Age of Mechanical Reproduction." In Illuminations, ed. Hannah Arendt, trans. Harry Zohn. New York: Schocken Books, 1969.

Deleuze, Gilles. Francis Bacon: the logic of sensation, trans. Daniel W. Smith. London: Continuum, 2004.

Frampton, Kenneth. Modern Architecture: A Critical History. London: Thames \& Hudson, 1980.

Kant, Immanuel. The Critique of Judgement, trans. James Creed Meredith. Oxford: At The Clarendon Press, 1969.

Lyotard, Jean-Francois. The Postmodern Condition: A Report on Knowledge, intr. Frederic Jameson, trans. Geoff Bennington \& Brian Massumi. Minnesota: University of Minnessota, 1984.

Lyotard, Jean-Francois. The Inhuman, trans. Geoffrey Bennington \& Rachel Bowlby. Stanford: Stanford University Press, 1991.

Montaner, Josep Maria. History of Contemporary Architecture Movements, Ideas and Creators in

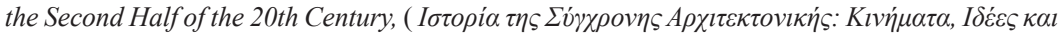

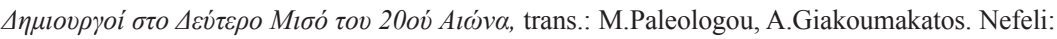
Athens, 2014.

Rancière, Jacques. The Emancipated Spectator, trans. Gregory Elliott. London: Verso, 2009.

Rancière, Jacques. The Distribution of the Sensible: Politics \& Aesthetics, trans. Gabriel Rockhill. London: Continuum, 2004.

Rancière, Jacques. Aesthetics and its Discontents, trans. Steven Corcoran. Cambridge: Polity Press, 2009.

Rancière, Jacques. Dissensus. On Politics \& Aesthetics, ed. \& trans. Steven Corcoran. London: Bloomsbury, 2010

Schiller, Friedrich. On the Aesthetic Education of Man in a Series of Letters, intr. \& trans. Reginald Snell. N.Y.: Dover Pbl., 2004.

Venturi, Robert. Complexity and Contradiction in Architecture. New York: Museum of Modern Art Papers on Architecture, c/1966.

Winckelmann, Johann Joachim. History of Ancient Art, trans. Giles Henry Lodge. Boston: James Munroe \& Co, 1849. 


\section{ESTETIKA ODRŽIVOSTI: ARHITEKTURA KAPSULE U GRADU I U PRIRODI Peter Šenk}

Arhitektura najmanjih mesta za stanovanje je u poslednje vreme izuzetno popularna tema. Kada su najmanja mesta za stanovanje kompaktna, dobro opremljena, povezana na mrežu, strukturno, funkcionalno i vizuelno prepoznata kao jedna stvar, privremena i pokretna ili prenosiva, mogu se označiti kao arhitektura kapsule. Budući da su po svojoj prirodi privremena, ova najmanja mesta za stanovanje, skloništa, redizajnirane kontejnerske jedinice, posebne tehnološke konstrukcije, paraziti i druge manifestacije koncepta kapsula obuhvataju logiku tehnoloških objekata s izrazitim arhitektonskim izrazom. To je, istovremeno, manifestacija pravila održivog dizajna, održive arhitekture i održivosti uopšte. U ovom kontekstu slučaj najmanjih mesta za stanovanje pokazuje svoju razliku u odnosu na druge održive arhitektonske pristupe i estetike. Podredjuje uopšteno održive pristupe sa izraženim značajem lokaliteta unutar globalnih sila, obično se oslanjajući na kontekst - lokaciju, lokalnu kulturu i karakteristike životne sredine itd. Estetski režim trenutnih, promenljivih, kontekstualnih i autonomnih arhitektonskih struktura se može posmatrati kao estetika drugosti, koja ih povezuje sa nasledjem egzistencijalnih eksperimenata modernog pokreta, novim brutalizmom, radikalnim eksperimentima 1960-ih i drugim avangardnim i neoavangardnim praksama dvadesetog veka, ali čvrsto postavljenim u kontekstu individualizovane, neodredjene, raspršene i dvosmislene savremenosti.

KLJUČNE REČI: ESTETIKA PROMENE, KAPSULE, NAJMANJA MESTA ZA STANOVANJE, MINIMALAN TRAG, DRUGOST, ESTETIKA ODRŽIVOSTI

\section{ESTETIKA I KULTUROLOŠKI ASPEKTI BAUHAUSA: \\ KA NOVOJ KONCEPCIJI}

\section{Christiane Wagner}

Ovaj članak pokriva nove mogućnosti Bauhaus pogleda na svet: stvaranje novih oblika za prikazivanje ljudskih ideala kroz fokus na estetiku i tehnologiju, u kombinaciji sa Nimajerovim (Niemeyer) uticajem na arhitekturu i dizajn. Novi stilovi i oblici nastali su kao izdanci Bauhausa, prenoseći vrednosti svake kulture kroz izgradnju kolektivne „slike“ sveta. Bauhaus današnjice izražava industriju kulture, dijalektički razmatrajući inovaciju i primenjenu umetnost kao put od modernog dizajna industrijske revolucije do „eko dizajna“. U tom smislu, Bauhaus je još uvek značajan po svojoj ulozi, povezujući umetnost, tehnologiju i industriju. Inovacija kao dinamično odredjivanje trenutka, prisutna u svim epohama, se shvata kao moćna sila za održavanje tradicije. Pored hronološkog zapisa o uticaju Bauhausa, razmatraju se i značajni Nimajerovi projekti. Na kraju su prikazane dve perspektive ,raskola“ izmedju arhitekture i tehnologije. Prva perspektiva se odnosi na ljudsku sposobnost stvaranja modela u arhitektonskoj praksi za usvajanje kao konfiguraciju prostora. Druga se odnosi na evoluciju tehnologija koje vode do toga da zamišljeno postaje stvarnost kroz vreme, kako je to opisao Hegel (1823).

KLJUČNE REČI: IZRADA PO MERI, TEHNOLOŠKI RAZVOJ, PROSTOR-VREME, NOVI OBLICI

\section{KLASIČNA ARHITEKTURA U OKVIRU KANTOVSKE ESTETIKE: IZMEĐU LIOTARA I RANSIJERA}

\section{Helen Tatla}

Potencijal koji je svojstven klasičnoj arhitekturi da predstavlja glavni arhitektonski izraz zapadne kulture budući da je grčka antika nastala zbog svog dualnog karaktera: iako izvire iz iskonskog jedinstva stvari izraženih mitom i religijom u arhaičnim vremenima, ona dobija svoj završni oblik u petom veku p. n. e., kao simbol demokratije i harmonične artikulacije sveta na osnovu filozofskog mišljenja. 
Postavljajući avangardnu umetnost u sferu kantovske uzvišenosti, Žan Fransoa Liotar (JeanFrancois Lyotard) se fokusira na nemogućnost apsolutnog odnosa razuma i percepcije ili između razmišljanja i slike, u savremenosti. On smatra da se u slučajevima kada se to dogodi radjaju politička čudovišta. On povezuje postmoderne izraze klasicizma u arhitekturi sa Frojdovim „Tumačenjem snova“" i kantovskom lepotom.

Pristup Žaka Ransijera (Jacques Ranciere) kantovstvu na osnovu estetskog razmatranja modernosti suprotan je onome koji je predložio Liotar. Umesto uzvišenog, Ransijer povezuje lepo s pukotinom izmedju razmišljanja i percepcije. U tom pogledu, fragmenti prošlosti mogu da podstaknu kreativni proces u sadašnjosti.

Cilj ovog istraživanja je da doprinese dijalogu o obnovljenom pristupu ulozi klasicizma u arhitekturi danas.

KLJUČNE REČI: KLASIČNA ARHITEKTURA, KANT, LIOTAR, MODERNOST, POLITIKA, POSTMODERNOST, RANSIJER

\section{FLUIDNO STANJE ARHITEKTURE}

\section{Bojana Jerković-Babović}

Ovaj rad se bavi promenama u kriterijumima arhitektonske estetike, transformacija statičnih u dinamične vrednosti podjednako figurativnih i nefigurativnih aspekata savremene arhitekture i njenog konteksta. Fluidno stanje arhitekture odnosi se na prepoznavanje konstantne promenljivosti koja se manifestuje u relacijama arhitekture i savremenom kultuloroškog konteksta globalizacije. Savremeni kontekst dinamizuje perceptivna iskustva svakodnevnice, uslove života i načine prostornih aproprijacija. U skladu sa tim, novi fenomeni umreženosti koji se manifestuju na informacionim, komunikacionim i prostornim nivoima transformišu grad i arhitekturu u konstantne procese tokova, kojima se njihovi elementi dematerijalizuju u nove fluidne, promenljive karakteristike. Vredosti arhitektonske estetike istovremeno se transformišu ka afirmaciji dogadjaja i efekata naspram statične formale celine, od objektivnih do intersubjektivnih estetskih prostornih iskustava.

Ovaj rad se bazira na hipotezi da savremenu arhitekturu karakteriše gubitak singularnosti objekta u odnosu sa uslovima konteksta i asimilacija karaktera pojedinačnih elemenata u fluidni karakter celine. Na taj način, arhitektonske projektantske principe karakteriše disperzija disciplinarnih granica i granica unutrašnjosti i spoljašnjosti, hibridnost i gubitak tipoloških definicija. Ovaj rad prikazuje kako dematerijalizacija arhitektonskih vrednosti transformiše savremeni arhitektonski prostor u kompleksan dinamički sistem infrastrukture, tokova, događaja i efekata.

KLJUČNE REČI: ARHITEKTONSKA ESTETIKA, ARHITEKTONSKO PROJEKTOVANJE, ESTETSKO ISKUSTVO, DINAMIČKE VREDNOSTI, FLUIDNOST, GLOBALIZACIJA

\section{KINEMATOGRAFIJA I ARHITEKTURA: MODERNA PERCEPCIJA Sônia Campaner Miguel Ferrari}

Esej Valtera Benjamina (Walter Benjamin) o bioskopu objašnjava njegove prognostičke vrednosti. Dok je pisao ovaj članak, njegova kritika kapitalističkog načina produkcije pokazala je pravac u kojem kapitalizam napreduje: ka sve većoj eksploataciji proletarijata, ali i ka svom vlastitom padu. Nas zanimaju ove prognoze koje potvrdjuju transformaciju umetnosti i njene funkcije, a koja našu pažnju usmeravaju na gubitak transcedencije i opadanja aure umetničkog dela. One u isto vreme pokazuju mogućnosti kojima se potvrđuje kontinuitet umetnosti koja ima drugačiju ulogu i dislokacija aure. Oblik umetnosti koji je pogodan za ovakvo razmišljanje je kinematografija i paralela koju je filozof povukao izmedju kinematografije i arhitekture. Namera nam je da se osvrnemo na ovu paralelu i urbane intervencije kao umetničke oblike estetske modernosti: to 